\title{
A JOGELLENESEN KÜLFÖLDRE VITT GYERMEKEK \\ VISSZAVITELÉNEK EGYES JOGI ASPEKTUSAI AZ EURÓPAI BÍRÓSÁG ESETJOGÁBAN
}

\section{Zoltán Angyal}

\section{BEVEZETÉS}

Az Európai Unió Bírósága (a továbbiakban: Bíróság) egy 2018 őszén hozott ítéletében fontos döntéseket hozott a jogellenesen külföldre vitt gyermekek visszavitelére vonatkozó uniós jogszabályok értelmezésével kapcsolatban. ${ }^{1}$ A döntés azért is különösen figyelemre méltó, mert az ítéletben a bírák nem követték mindenben a fötanácsnoki indítványban javasolt értelmezést. ${ }^{2}$ Jelen tanulmány célja, hogy részletesen bemutassa az ügy jogi hátterét, a tényállásbeli előzményeket, a tagállami bíróság által az előzetes döntéshozatali eljárásban feltett kérdéseket, és a Bíróság arra adott válaszait a jogi indokolásukkal együtt. Ennek során rávilágítok azokra a pontokra is, amelyekről az ügyben eljáró főtanácsnok más véleményt fogalmazott meg.

\section{A jogi háttér}

A 2201/2003/EK rendelet - amelyet "Brüsszel IIa" rendeletnek is neveznek ${ }^{3}$ - az az uniós jogszabály, amely többek között akkor válik relevánssá, amikor egy szülői felelősségre vonatkozó határozat valamely másik tagállamban történő elismertetéséröl és végrehajtásáról van szó. A gyermekeknek a felügyeleti jog megsértésével történő jogellenes elvitelének eseteiben ez a rendelet beépíti és kiegészíti a gyermekek jogellenes külföldre vitelének polgári jogi vonatkozásairól szóló, 1980, október 25-én Hágában kötött egyezmény rendelkezéseit. A jelen tanulmány által vizsgált ügyben az a kérdés merült fel, hogy milyen kapcsolat áll fenn e két jogszabály között egy olyan esetben, amikor egy angol család annak veszélye elől, hogy a gyermekeiket a helyi gyermekvédelmi hatóság elveszi

\footnotetext{
1 A Bíróság 2018. szeptember 19-i ítélete a C-325/18. PPU. és C-375/18. PPU. sz. egyesített ügyekben.

2 Juliane Kokott fötanácsnok 2018. augusztus 7-i indítványa a C-325/18. PPU. és C-375/18. PPU. sz. egyesített ügyekben.

3 A 2004. december 2-i 2116/2004/EK tanácsi rendelettel (HL 2004. L 367, 1. o.) módosított, a házassági ügyekben és a szülői felelősségre vonatkozó eljárásokban a joghatóságról, valamint a határozatok elismeréséröl és végrehajtásáról, illetve az 1347/2000/EK rendelet hatályon kívül helyezéséről szóló, 2003. november 27-i 2201/2003/EK tanácsi rendelet (HL 2003. L 338, 1. o. ; helyesbítések: HL 2013. L 82, 63. o. ; HL 2018. L 33, 5. o. ; magyar nyelvü különkiadás 19. fejezet, 6. kötet, 243. o.).
} 
tőlük, Írországba szökik egy két- vagy háromnapos csecsemővel, valamint két idősebb, egy három- és egy ötéves gyermekkel.

Az elözetes döntéshozatal iránti kérelmek az Európai Unió Alapjogi Chartája (a továbbiakban: Charta) 47. cikkének, valamint a házassági ügyekben és a szülői felelősségre vonatkozó eljárásokban a joghatóságról, valamint a határozatok elismeréséről és végrehajtásáról, illetve az 1347/2000/EK rendelet hatályon kívül helyezéséről szóló, 2003. november 27-i 2201/2003/EK tanácsi rendelet (a továbbiakban: rendelet) 11. cikkének és 33. cikke (5) bekezdésének értelmezésére vonatkozik.

E kérelmeket a Hampshire County Council (Hampshire megyei tanács, Egyesült Királyság, a továbbiakban: HCC), valamint C. E. és N. E. (a továbbiakban: az érintett szülők) között a következők tárgyában folyamatban lévő eljárásban terjesztették elö: három olyan kiskorú gyermek Egyesült Királyságba való visszavitele, akiket az érintett szülők Írországba vittek e gyermekek gyámság alá helyezésének elkerülése céljából, és az e szülők által Írországban benyújtott, arra irányuló ideiglenes intézkedés iránti kérelem, hogy felfüggesszék e három gyermek közül a legfiatalabb, és adott esetben a többi gyermek Egyesült Királyságban való örökbefogadását.

\subsection{Nemzetközi jog}

A gyermekek jogellenes külföldre vitelének polgári jogi vonatkozásairól szóló, Hágában 1980. október 25-én kötött egyezmény ${ }^{4}$ célja többek között, amint az a preambulumából kitünik, hogy nemzetközileg védjék a gyermekeket jogellenes elvitelük vagy visszatartásuk káros következményeitől, és hogy megteremtsék a gyermekeknek a szokásos tartózkodási helyük szerinti államba történő azonnali visszavitelük biztosítására szolgáló eljárást. Ezen egyezmény 1983. december 1-jén lépett hatályba, és az Európai Unió valamennyi tagállama részese. Az egyezmény 3. cikke értelmében: a gyermek elvitele vagy elrejtése jogellenes, ha az:

- sérti az azon állam joga szerint egy személynek, egy intézménynek vagy más szervnek - akár együttesen, akár kizárólagosan - juttatott felügyeleti jogokat, amelyben a gyermeknek az elvitelét vagy elrejtését közvetlenül megelőzően a szokásos tartózkodási helye volt; és

- ezeket a jogokat az elvitel vagy elrejtés időpontjában - együttesen vagy külön-külön - gyakorolták vagy azok gyakorlásában éppen az elvitel vagy elrejtés akadályozta meg az arra jogosultakat.

Az egyezmény rögzíti továbbá, hogy a gyermek jogellenes elvitelének vagy elrejtésének a 3. cikk szerinti esetében a gyermek jogellenes elvitelétöl

4 Kihirdette : az 1986. évi 14. tvr. ; a továbbiakban : 1980. évi Hágai Egyezmény. 
vagy elrejtésétől az eljárásnak azon Szerződő Állam igazságügyi vagy államigazgatási szervei előtti megindításáig, ahol a gyermek van, egy évnél kevesebb idő telt el, az érintett hatóság haladéktalanul elrendeli a gyermek visszavitelét. ${ }^{5}$ Utóbbi alól kivétel az, ha a gyermeket visszavitele testi vagy lelki károsodásnak tenné ki vagy bármi más módon elviselhetetlen helyzetet teremtene számára. ${ }^{6}$

\subsection{Az uniós jog}

A 2201/2003/EK rendelet meghatározza egyebek mellett a jogellenes elvitel vagy visszatartás fogalmát. Ennek minősül egy gyermek elvitele vagy visszatartása, ha azt sérti a határozat vagy jogszabály hatálya alapján, illetve azon tagállam joga szerint jogilag kötelező megállapodás útján szerzett felügyeleti jogokat, ahol a gyermek közvetlenül az elvitel vagy visszatartás előtt szokásos tartózkodási hellyel rendelkezett; és feltéve, hogy az elvitel vagy visszatartás időpontjában a felügyeleti jogokat közösen vagy önállóan ténylegesen gyakorolták, vagy gyakorolták volna, ha az elvitelre vagy visszatartásra nem kerül sor. A felügyeletet közösen gyakoroltnak kell tekinteni, ha határozat vagy jogszabály hatálya értelmében a szülői felelősség egyik gyakorlója nem határozhat a gyermek tartózkodási helyéről a szülői felelősség másik gyakorlójának hozzájárulása nélkül. ${ }^{7}$

A gyermek visszavételéről a rendelet azt mondja ki, hogy arra akkor kerülhet sor, amennyiben a felügyeleti jogokat gyakorló személy, intézmény vagy más szerv egy tagállam illetékes hatóságaihoz folyamodik azért, hogy azok a Hágai Egyezmény alapján hozzon határozatot annak érdekében, hogy kérelmezze annak a gyermeknek a visszavitelét, akit közvetlenül a jogellenes elvitel, illetve visszatartás előtti szokásos tartózkodási helye szerinti tagállamtól eltérő tagállamba jogellenesen elvittek, illetve ott visszatartottak. ${ }^{8}$

A perfüggőséggel kapcsolatban az uniós jogszabály előírja, hogy amennyiben azonos jogalapból származó, ugyanarra a gyermekre vonatkozó szülői felelősséggel kapcsolatos eljárást különböző tagállamok bíróságai előtt indítottak, a később megkeresett bíróság az elsőként megkeresett bíróság joghatóságának megállapításáig hivatalból felfüggeszti az eljárást. Amennyiben az elsőként megkeresett bíróság joghatóságát megállapítják

\footnotetext{
5 Lásd az egyezmény 12 . cikkét.

6 Lásd az egyezmény 13 . cikkét.

Lásd a rendelet 2 . cikkét.

8 Lásd a rendelet 11 . cikkét.
} 
a később megkeresett bíróság az előbbi bíróság javára megállapítja saját joghatóságának hiányát. ${ }^{9}$

A jogorvoslatokat illetően a rendelet rögzíti, hogy a végrehajthatóság megállapítása elleni jogorvoslatot a végrehajthatóságotmegállapító határozat kézbesítésétől számított egy hónapon belül kell benyújtani. Ha az a fél, akivel szemben a végrehajtást kérik, más tagállamban rendelkezik szokásos tartózkodási hellyel, mint amelyben a végrehajthatóvá nyilvánításra sor került, a jogorvoslati határidő akár a személyes, akár a lakóhelyen történő kézbesítés időpontjától számított két hónap. Ez az időtartam a távolságra tekintettel nem hosszabbítható meg. ${ }^{10}$

A rendelet és a Hágai Egyezmény viszonyát egyértelmüen rendezi a jogszabály azzal, hogy a tagállamok közötti kapcsolatokban e rendelet elsőbbséget élvez a következő egyezményekkel szemben, amennyiben azok az e rendelettel szabályozott ügyekre vonatkoznak. ${ }^{11}$

\subsection{Azír jog}

Az ír felsőbíróságok eljárási szabályzata korábbi változatában úgy rendelkezett, hogy a kereset elbírálásáig automatikusan fel kell függeszteni a végrehajtásról szóló végzés végrehajtását. Az automatikus felfüggesztés szabályát azonban nem ítélték megfelelőnek a 2201/2003 rendelet hatálya alá tartozó ügyekben. Ezért az újabb szabályozás immár úgy rendelkezik, hogy az ítélet vagy határozat végrehajtására sor kerülhet letelte elött. További releváns rendelkezése az tagállami jogrendszernek az, amely szerint a végrehajthatóságot megállapító határozatnak tartalmaznia kell egy olyan megjegyzést, amely szerint az ítélet vagy határozat végrehajtása bíróság előtti kérelemre felfüggeszthető, ha az eredeti eljárás helye szerinti tagállamban rendes jogorvoslatot nyújtottak be.

\section{Az alapeljárások}

Az ügy egy olyan családra vonatkozott, amelynek tagjai a következők: egy 24 éves anya, annak három - egy hatéves, egy négyéves és egy körülbelül tizenegy hónapos - gyermeke, valamint a férje, aki 26 éves, és aki a csecsemő apja, a két idősebb gyermeknek pedig a mostohaapja.

A brit állampolgárságú, korábban az Egyesült Királyságban együtt élő házaspár szülők 2017. szeptember 5-én komppal érkeztek Írországba három gyermekkel, akik közül az egyik mindössze két nappal korábban

9 Lásd a rendelet 19 . cikkét.

10 Lásd a rendelet 33. cikkét.

11 Lásd a rendelet 60 . cikkét. 
született. N. E. a három gyermek anyja, C. E. pedig a három gyermek közül csupán a legfiatalabbnak az apja. 2017 júniusában az Egyesült Királyságban elrendelték a két idősebb gyermek ideiglenes hatályú elhelyezését. A HCC-nek ebben az összefüggésben felmerült aggályai többek között a házban uralkodó higiénia és tisztaság hiányával, a második gyermek súlygyarapodásával, a második gyermek apja által az anya ellen együttélésük alatt elkövetett családon belüli erőszakkal, a második gyermek apja által kender birtoklásával, valamint összességében azzal kapcsolatban merültek fel, hogy fennállt a veszélye annak, hogy a gyermekek felügyeletét elhanyagolják. Továbbá az is felmerült, hogy az egyik gyermek nem baleseti eredetü sérülést szenvedett, és nem volt kizárható annak lehetősége, hogy az elkövető C. E. volt. 2017. szeptember 8-án a brit hatóságok gyermekek biztonságát érintő aggályai miatt a High Court of Justice (England and Wales) végzésben elrendelte egyrészt a három gyermek gyámság alá helyezését, a HCC-re ruházva a felügyeleti jogokat (a továbbiakban: gyámság alá helyező végzés), másrészt a három gyermek visszavitelét (a továbbiakban: visszavitelt elrendelő végzés). Ugyanezen a napon a HCC kapcsolatba lépett a megfelelö ír hatósággal, a Child and Family Agency-vel (gyermekés családvédelmi szolgálat, Írország, a továbbiakban: szolgálat), és jelezte azon szándékát, hogy a High Courttól (England and Wales) a három gyermek visszavitelét elrendelő határozat meghozatalát kéri. A szolgálat azt válaszolta, hogy az ilyen határozatot a 2201/2003 rendelet alapján kell végrehajtani. Ugyanazon a napon később a HCC tájékoztatta a szolgálatot, hogy e bíróság szintén aznap visszavitelt elrendelő határozatot fogadott el.

Az E. család írországi lakóhelyén több látogatást is tettek, de a szolgálat semmilyen aggasztó jelet nem talált a gyermekeket illetően. Az érintett szülők arról tájékoztatták a szolgálatot, hogy korábban azt a tanácsot kapták, utazzanak Írországba annak érdekében, hogy a szociális szolgálatokat elkerüljék és megakadályozzák a három gyermek elhelyezését. A szolgálat közölte a szülőkkel, hogy a HCC által nyújtott információk alapján a három gyermek ideiglenes hatályú elhelyezéséről szóló határozat elfogadását fogja kérni. Azt is közölte, hogy a HCC kérheti a High Courttól (felsőbíróság, İrország) a három gyermek visszavitelét elrendelő végzés elismerését, és ha e kérelmet az helybenhagyja, a gyermeket vissza kell vinni az Egyesült Királyságba. 2017. szeptember 14-én a District Court (kerületi bíróság, Írország) a három gyermek ideiglenes felügyeletét a szolgálatra bízta, amely a gyermekeket nevelőszülöknél helyezte el. Az érintett szülők beleegyeztek ezen ideiglenes hatályú elhelyezésbe, nem ismerték el azonban annak megalapozottságát. 
A szolgálat az elhelyezéssel kapcsolatos tervre vonatkozó megbeszélést tartott a szülőkkel. 2017. szeptember 21-én a High Court (felsőbíróság, Írország) a 2201/2003 rendelet III. fejezete alapján végzést fogadott el, elismerve a gyámság alá helyező végzést és elrendelve e határozat „e területen való végrehajtását” (a továbbiakban: ex parte végzés). Ugyanezen a napon a három gyermeket átadták a HCC szociális munkásainak, és visszavitték az Egyesült Királyságba. A HCC szociális szolgálatai kifejezetten kérték a megfelelő ír hatóságoktól, hogy ne lépjenek kapcsolatba az érintett szülőkkel, mivel úgy vélték, hogy fennállt a szökés veszélye. A szülőket tehát csak utólag, vagyis a három gyermek visszavitelének napján tájékoztatták telefonon, és az ex parte végzést hivatalosan csupán másnap kézbesítettek nekik. A szülők megkísérelték a gyámság alá helyező végzéssel szembeni fellebbezést, de a Court of Appeal (England and Wales) (fellebbviteli bíróság, Anglia és Wales) 2017. október 9-én nem engedélyezte a fellebbezést. 2017. november 24-én a szülők a High Court (felsőbíróság, Írország) előtt keresetet indítottak az ex parte végzéssel szemben. 2018. január 18-án e keresetet amelyet két nappal a 2201/2003 rendelet 33. cikkének (5) bekezdésében megállapított határidő lejártát követően terjesztettek elő - késedelem miatt elutasították, mivel az e rendelkezésben előírt határidő imperatív volt, és az eljáró bíróság nem rendelkezett hatáskörrel annak meghosszabbítására. A szülők megtámadták a határozatot a kérdést előterjesztő bíróság előtt.

Összefoglalva: a helyi hatóság tehát a szülők távollétében először egy angol bíróságtól olyan végzést kapott, amely a gyermekeket gyámság alá helyezi, és elrendeli Angliába történő visszavitelüket, majd ezt követően egy ír bíróságtól a 2201/2003 rendelet alapján végrehajthatóságot megállapító határozatot. Végül, még azt megelőzően, hogy ezt a végrehajthatóságot megállapító határozatot a szülőknek kézbesítették volna, az angol hatóság, amelyet annak ír megfelelői segítették, teljesítette a végrehajtást, és a gyermekeket a szülök tudta nélkül visszavitte Angliába. Utóbbiak tehát Írországban a 2201/2003 rendeletben elöírt határidőhöz képest kétnapos késéssel jogorvoslati kérelmet nyújtottak be a végrehajthatóságot megállapító határozattal szemben. Időközben az angol hatóság a csecsemő örökbefogadására irányuló eljárást indított Angliában.

\section{Az előzetes döntéshozatalra feltett kérdések}

Az ír fellebbviteli bíróság a C-325/18. sz. ügyben úgy határozott, hogy az eljárást felfüggeszti, és előzetes döntéshozatal céljából a következő kérdéseket terjeszti a Bíróság elé. A kérdések lényege a következő volt: 
1. Amennyiben a szülők a gyermekeket a szokásos tartózkodási helyük szerinti országból állítólag jogellenesen, a lakóhely szerinti állam közigazgatási szerve által megszerzett bírósági végzést megszegve elviszik, az említett közigazgatási szerv kérheti-e a rendelet alapján a gyermek e területre való visszavitelét elrendelő bírósági végzés végrehajtását valamely más tagállam bíróságaitól, vagy ez az említett rendeletnek és a Hágai Egyezménynek a jogellenes megkerülését jelentené, vagy az érintett szerv részéről más módon joggal való visszaélésnek minősülne?

2. A rendelet végrehajtási rendelkezéseit érintő esetben meghosszabbítható-e a jogorvoslati határidő, amennyiben a késedelem lényegében csekély mértékü és a nemzeti eljárási jog alapján a határidőt egyébként meghosszabbíthatták volna?

3. A második kérdéstől függetlenül, amennyiben valamely külföldi közigazgatási hatóság a gyerekeket, akikre a jogvita irányul, a rendelettel összhangban egyéb érdekeltek meghallgatása nélkül elrendelt végrehajtás alapján valamely tagállam területéről azt megelőzően viszi el, hogy a szülök részére a végrehajtásról szóló végzést kézbesítették volna, és ezzel megfosztja őket azon joguktól, hogy a jogorvoslat idejére e végzés felfüggesztését kérjék, ez az eljárás oly mértékben sérti-e az emberi jogok és alapvető szabadságok védelméről szóló európai egyezményt (EJEE) és a Charta alapján a szülőket megillető jogok lényegét, hogy a jogorvoslati határidőt meg kell hosszabbítani?".

Az érintett szülők ezt követően a kérdést előterjesztő bíróság előtt ideiglenes intézkedés iránti kérelmet terjesztettek elő a három gyermek örökbefogadási eljárásának felfüggesztése érdekében. A HCC azon szándékáról nyilatkozott, hogy csak a legfiatalabb gyermeket adja örökbe, mivel a másik két gyermek akkor már az Egyesült Királyságban, az egyikük apjánál lakott. A HCC-t az alapeljárás „feleként” nevezték meg, azonban a kérdést előterjesztő bíróság előtti ezen eljárásban nem vett részt, és nem gyakorolta az e bíróság előtti meghallgatáshoz való jogát. Az ír fellebbviteli bíróság ebben a másik, C-375/18. sz. ügyben úgy határozott, hogy az eljárást felfüggeszti, és előzetes döntéshozatal céljából egy újabb kérdést terjeszt a Bíróság elé. A kérdés arra irányult, hogy összeegyeztethető-e az uniós joggal és különösen a rendelettel, hogy valamely tagállam bírósága ideiglenes intézkedést elrendelő végzést hozzon közvetlenül egy másik tagállam hatóságának címezve, megakadályozva e hatóságot abban, hogy az megindítsa a gyermekek örökbefogadását az említett tagállam bíróságai előtt, amennyiben a közvetlenül e hatóságnak címzett intézkedést az teszi 
szükségessé, hogy védelemben részesítsék a rendelet szerinti végrehajtási eljárás feleinek jogait?

A Bíróság elnöke nem sokkal ezt követően elrendelte a C-325/18. és a C-375/18. sz. ügy egyesítését az írásbeli és a szóbeli szakasz lefolytatása, valamint az ítélet meghozatala céljából. ${ }^{12}$

A kérdést előterjesztő bíróság kérte az előzetes döntéshozatal iránti kérelem sürgősségi eljárásban történő elbírálását. ${ }^{13}$ Kérelme indokolásaként a tagállami bíróság arra hivatkozott, hogy a C-325/18. sz. ügy sürgősségét tekintettel a gyermekek örökbefogadására irányuló, a HCC által lefolytatandó és a három gyermek anyja által kifogásolt eljárásra. Ami a legfiatalabb gyermeket illeti, e gyermek apja szintén elleneztr az örökbeadást. Másrészt a kérdést előterjesztő bíróság azt állította, hogy a C-375/18. sz. ügyben a sürgősségi előzetes döntéshozatali eljárás iránti kérelem ideiglenes intézkedés iránti eljárásból ered, amelyet megfosztana a hatékony érvényesülésétől az, ha a Bíróság nem sürgősségi előzetes döntéshozatali eljárást folytatna le. A Bíróság megállapította, hogy egyrészt az értelmezendő cikk az EUM-Szerződés harmadik részének a szabadságon, a biztonságon és a jog érvényesülésén alapuló térségre vonatkozó V. címe alatt található, így az sürgősségi előzetes döntéshozatali eljárás tárgya lehet. Másodsorban megállapították, hogy az alapeljárások három hat év alatti gyermeket érintenek, akik közel egy éve el vannak választva anyjuktól, és hogy a HCC lépéseket tett az Egyesült Királyságban annak érdekében, hogy a legkisebb gyermeket örökbe fogadják. Ezekre tekintettel a Bíróság első tanácsa 2018. június 11-én úgy határozott, hogy helyt ad a kérdést előterjesztő bíróság azon kérelmének, hogy az előzetes döntéshozatal iránti kérelmet sürgősségi eljárásban bírálják el.

\section{A Bíróság válaszai és jogi indokolásuk \\ 4.1. A C-325/18. sz. ügy elsö kérdéséröl}

Első kérdésével az ír bíróság arra kereste a választ, hogy a rendeletet úgy kell-e értelmezni, hogy ha azt állítják, hogy a gyermekeket jogellenes vitték el, a gyermekek korábbi szokásos tartózkodási helye szerinti tagállam bíróságának e gyermekek visszavitelét elrendelő határozata ezen általános rendelkezések értelmében a fogadó tagállamban végrehajthatóvá nyilvánítható-e. Azaz a tagállami bíróság konkrétan arra kereste a választ, hogy a HCC-nek ki kellett volna-e merítenie a fogadó tagállamban a Hágai Egyezmény szerint rendelkezésre álló

12 Lásd a Bíróság elnökének erre vonatkozó 2018. június 11-i határozatát.

13 Lásd a Bíróság eljárási szabályzatának 107. cikkét. 
jogorvoslatokat mielőtt a rendelet alapján megkísérelte elismertetni és végrehajtani a gyámság alá helyező végzést.

A fötanácsnoki indítványban rögzített gondolatmenet a következő volt. Az indítvány szerint meg kell különböztetni egyfelől azokat a határozatokat, amelyek a szülői felelősségre vonatkozó határozat következményeként magukban foglalják vagy elrendelik a gyermeknek az eredeti eljárás helye szerinti tagállamba történő visszavitelét, másfelől pedig azokat a határozatokat, amelyek egy személynek, a jelen esetben egy gyermeknek a valamely tagállam területére történő visszavitelét a szülői felelősségre vonatkozó határozattól függetlenül rendelik el: a két határozattípus magában foglalhatja a gyermeknek az eredeti eljárás helye szerinti tagállamba történő visszavitelét, azonban csak az előbbi határozatok nyilváníthatók végrehajthatóvá a 2201/2003 rendelet alapján a megkeresett tagállamban. A főtanácsnok szerint nem kizárt, hogy a tagállami bíróságok a nemzeti joguk alapján a szülöi felelősségre vonatkozó határozat meghozatalától függetlenül rendelhetik el egy gyermeknek a területükre történő visszavitelét, ugyanakkor ez a visszavitelt elrendelő végzés - amennyiben nem minősül a 2201/2003 rendelet alapján elfogadott, visszavitelt elrendelő határozatnak - nem tartozik a rendelet tárgyi hatálya alá. Az indítvány szerint így első kérdésre azt a választ kell adni, hogy amennyiben a gyermekeket állítólag jogellenesen vitték el a szokásos tartózkodási helyük szerinti tagállamból egy másik tagállamba, az eredeti eljárás helye szerinti tagállam bírósága által a 2201/2003 rendelet 11. cikkében elöírt eljáráson kívül és a szülői felelősségre vonatkozó határozattól függetlenül hozott, az ezen gyermekek visszavitelét elrendelö határozat nem hajtható végre e rendelet III. fejezetének rendelkezéseivel összhangban. Ugyanakkor ilyen körülmények között az eredeti eljárás helye szerinti tagállam bírósága által hozott, a szülői felelősségre vonatkozó határozat, amely magában foglalja a gyermek e tagállamba történő visszavitelét, végrehajtható e rendelkezésekkel összhangban.

A Bíróság ettől részben eltérő következtetésre jutott. Az ítélet mindenekelőtt megállapította azt, hogy bár e rendelet célja a preambuluma értelmében, hogy a szülői felelősségére vonatkozó eljárásokban a joghatóságról, valamint a határozatok elismeréséről és végrehajtásáról szóló szabályok megállapításával létrehozzon egy, a bírósági határozatok kölcsönös elismerése elvén alapuló valóságos jogi térséget, miközben az Egyezmény tárgya az 1. cikkének a) pontja szerint biztosítani a bármelyik szerződő államba jogellenesen elvitt vagy ott visszatartott gyermekek azonnali visszajuttatását, szoros kapcsolat áll fenn e két jogforrás között, 
amelyeknek közös célja lényegében, hogy visszatartsanak a gyerekek jogellenes külföldre vitelétől, és ha ez megtörténik, elérjék a gyermekeknek a szokásos tartózkodási helyük szerinti államba történő haladéktalan visszavitelét. ${ }^{14}$ A szóban forgó két jogszabály kapcsolatát a rendelet akként pontosítja, hogy a tagállamok bíróságainak a rendeletet kell alkalmazniuk az 1980. évi Hágai Egyezmény szerinti visszavitelre irányuló eljárásra. A Bíróság ebből azt a következtetést vonta le, hogy e rendelkezések nem követelik meg, hogy valamely személy, szerv vagy hatóság - ha állítólag gyermek jogellenes külföldre vitelére került sor - az 1980. évi Hágai Egyezmény alapján kérje e gyermeknek a szokásos tartózkodási helye szerinti államba való haladéktalan visszavitelét.

A Bíróság továbbá megvizsgálta azt, hogy a visszavitelt elrendelő végzés a rendelet tárgyi hatálya alá tartozik-e, amit C. E. vitatott. A kiindulási pont a rendelet tárgyi hatályára vonatkozó előírása volt, amely szerint a rendeletet a bíróság jellegétöl függetlenül alkalmazni kell a többek között a szülői felelősség megállapításával, gyakorlásával, átruházásával, korlátozásával vagy megszüntetésével kapcsolatos polgári ügyekben. A szülői felelősséggel kapcsolatos ügyek különösen a következőkkel foglalkoznak: felügyeleti jog, gyámság, a gyermek személyének, illetve vagyonának gondozásával megbízott olyan személyek vagy szervek kijelölése és feladatai, amelyek képviselik vagy támogatják a gyermeket, valamint a gyermek nevelőszülőknél való elhelyezése vagy intézményi gondozásba helyezése. A High Court (felsőbíróság, Írország) által a rendelet alapján elfogadott ex parte végzés elismerte a gyámság alá helyező végzést, és azt Írországban végrehajthatóvá nyilvánította. Nem vitatott, hogy a három gyermek visszavitelére vonatkozó kérelem nem az 1980. évi Hágai Egyezményen alapult, és hogy a gyámság alá helyező végzés rendelkező része több elemből áll, többek között a gyermekek állami gondozásba vételéből és a visszavitelt elrendelő végzésből. A Bíróság ezek alapján megállapította, hogy a gyermekeket gyámság alá helyezó és azok visszavitelét elrendelő olyan határozat, mint amely az alapeljárás tárgyát képezi, és amelynek a végrehajtását az ír bíróságtól kérték, a rendelet szerint a szülői felelősség megállapítására és/vagy gyakorlására és/vagy korlátozására vonatkozik, továbbá a rendelet értelmében a "felügyeleti joggal" és/vagy a "gyámsággal" foglalkozik. Ezért az ilyen határozat e rendelet tárgyi hatálya alá tartozik.

A Bíróság ennek megfelelően úgy döntött, hogy az első kérdésre azt a választ kell adni, hogy a rendeletet úgy kell értelmezni, hogy ha azt állítják,

14 Lásd ehhez : 2008. július 11-i Rinau ítélet, C-195/08 PPU, EU:C:2008:406, 48. és 52. pont. 
hogy a gyermekeket jogellenes vitték el, a gyermekek korábbi szokásos tartózkodási helye szerinti tagállam bíróságának az említett gyermekek visszavitelét elrendelő és a szülői felelősségre vonatkozó határozatát követő határozata ezen általános rendelkezések értelmében a fogadó tagállamban végrehajthatóvá nyilvánítható.

\subsection{A C-325/18. sz. ügyben előterjesztett második és harmadik kérdésröl}

A második és a harmadik kérdésével az ír bíróság arra kereste a választ, hogy a rendelet 33. cikkének a Charta 47. cikkére tekintettel értelmezett (1) bekezdését úgy kell-e értelmezni, hogy egyrészt azzal olyan helyzetben, mint amely az alapeljárás tárgya, ellentétes a gyámsága alá helyezést és a gyermekek visszavitelét elrendelő, továbbá a megkeresett tagállamban azelőtt végrehajthatóvá nyilvánított tagállami bírósági határozatnak a végrehajtása, hogy az érintett szülőknek kézbesítették volna az e határozat végrehajthatóságát megállapító nyilatkozatot, másrészt az e 33. cikk (5) bekezdésében előírt keresetindítási határidőre kell hivatkozni azon személy esetében, akivel szemben az említett határozat végrehajtását kérték.

A Bíróság már korábbi ügyekben megállapította, hogy hogy annak elkerülése érdekében, hogy a végrehajthatóvá nyilvánítás tárgyában hozott határozat ellen benyújtott jogorvoslat felfüggesztő hatálya megkérdőjelezhesse a rendelet 31 . cikkében elöírt rövid határidőt, az elhelyezést elrendelő határozat azon időponttól végrehajtható, amikor a megkeresett tagállam bírósága az említett 31. cikknek megfelelően megállapította e határozat végrehajthatóságát. ${ }^{15} \mathrm{Az}$ ítélkezési gyakorlat részéve vált az a döntés is, amely szerint a megkeresett tagállam bíróságának, annak érdekében, hogy ne fossza meg hatékony érvényesülésétől a rendeletet, a végrehajthatóvá nyilvánítás iránti kérelemre vonatkozó határozatot különös gyorsasággal kell meghoznia, és a megkeresett tagállam bíróságának ilyen határozata ellen benyújtott jogorvoslat nem bírhat felfüggesztő hatállyal. ${ }^{16}$ Az új jogértelmezési problémát az okozta, hogy az előző ítéletek alapján nem dönthető el előre az a külön kérdést, hogy az ex parte eljárás szakaszában végrehajthatóvá nyilvánított határozat végrehajtható-e a kézbesítés előtt.

15 Lásd ehhez : 2012. április 26-i Health Service Executive ítélet, C-92/12 PPU, EU:C:2012:255, 125. pont.

16 Lásd ehhez : 2012. április 26-i Health Service Executive ítélet, C-92/12 PPU, EU:C:2012:255, 129. pont. 
A kérdés nehézségét jelezte az is, hogy maga a Bíróság is felhívta a figyelmet arra, hogy önmagában a rendelet szövege alapján nem lehetséges a feltett kérdésekre válaszolni. E rendelkezés elöírja ugyanis, hogy a végrehajtási határozat elleni jogorvoslat benyújtására nyitva álló határidő e határozat kézbesítésétől kezdődik, nem jelöli meg pontosan, hogy a végrehajtásra sor kerülhet-e ezen kézbesítés előtt. E kézbesítési kötelezettség, valamint a jogorvoslatra vonatkozó információk azzal együtt történő átadása lehetővé teszi, hogy az a fél, aki ellen a végrehajtást kérték, hatékony jogorvoslati joggal rendelkezzen.

Következésképpen annak megállapításához, hogy az érintett félnek a rendelet 33. cikke értelmében véve lehetősége volt jogorvoslati kérelem előterjesztésére a végrehajthatóságot megállapító határozattal szemben, az szükséges, hogy ismerje e határozat tartalmát, ami egyben feltételezi, hogy azt részére kézbesítették, vagy közölték vele. ${ }^{17} \mathrm{Az}$ ír jog alapján végrehajthatóságot megállapító határozatnak tartalmaznia kell egy olyan megjegyzést, amely szerint ,,az ítélet vagy határozat végrehajtása bíróság előtti kérelemre felfüggeszthető, ha az eredeti eljárás helye szerinti tagállamban rendes jogorvoslatot nyújtottak be”. A Bíróság szerint az a lehetőség, hogy a nemzeti jog alapján kérhető az ilyen határozat végrehajtásának felfüggesztése a hatékony jogorvoslathoz való alapvető jog, illetve általánosságban a védelemhez való jogok lényeges garanciájának minősül, amely felfüggesztésre többek között akkor kerülhet sor, ha valamely határozat végrehajtása nyilvánvalóan rendkívüli következményeket vonna maga után. A Bíróság előtti tárgyaláson a HCC azt állította, hogy a határozat haladéktalan végrehajtását "általában a szökés veszélye” tette szükségessé. A Bíróság azonban megállapította, hogy a gyermekek 2017. szeptember 14. óta Írországban befogadó otthonban voltak elhelyezve. Következésképpen úgy tünik, hogy az Egyesült Királyságba való visszavitelüket elrendelő határozat végrehajtását nem jellemezte különös sürgősség. A Bíróság ezért úgy vélte, hogy a rendelettel ellentétes a gyámsága alá helyezést és a gyermekek visszavitelét elrendelő, továbbá a megkeresett tagállamban azelőtt végrehajthatóvá nyilvánított tagállami bírósági határozatnak a végrehajtása, hogy az érintett szülőknek kézbesítették volna az e határozat végrehajthatóságát megállapító nyilatkozatot.

Az ír bíróság arra is kereste a választ, hogy ilyen körülmények között a rendelet 33. cikkének (5) bekezdését úgy kell-e értelmezni, hogy az e rendelkezésben elöírt keresetindítási határidőre hivatkozni kell az

17 Lásd ehhez: 2006. december 14-i ASML-ítélet, C-283/05, EU:C:2006:787, 40. pont. 
érintett szülőkkel szemben. Az alapeljárásban nem volt vitatott, hogy a végrehajthatóságot megállapító határozatot ténylegesen kézbesítettek az érintett szülőknek. A Bíróság szerint kétségtelen, hogy a szülőket megfosztották azon joguktól, hogy a visszavitelt elrendelő végzés végrehajtásának felfüggesztését kérjék, mivel a kézbesítésre e határozat végrehajtását követően került sor. Mindazonáltal a jogaik e sérelme nincs hatással az e határozat kézbesítésével meginduló keresetindítási határidőre. Ilyen körülmények között a rendelet 33. cikkének (5) bekezdésében elöírt keresetindítási határidőt az eljáró bíróság nem hosszabbíthatja meg.

Itt kell megjegyezni azt, hogy a fötanácsnok ezzel részben ellentétes következtetésre jutott. Az indítványa értelmében a rendelet végrehajtási rendelkezéseit érintő ügyben az eljáró bíróság a tagállamok eljárási autonómiájának elve értelmében hatáskörrel rendelkezik arra, hogy az említett rendelet 33. cikkének (5) bekezdésében elöírt jogorvoslati határidőt meghosszabbítsa. A főtanácsnok szerint az érintett bíróság feladata, hogy az adott ügy összes körülménye alapján, valamint az egyenértékűség és a tényleges érvényesülés elvére tekintettel megvizsgálja azt, hogy ezt a meghosszabbítást engedélyezni kell-e. ${ }^{18}$ Az indítvány azzal indokolta ezt a megközelítést, hogy a rendelet csak azt mondja ki, hogy a jogorvoslat benyújtására nyitva álló határidő a távolságra tekintettel nem hosszabbítható meg, e határidőnek a távolságtól eltérő más okból történő meghosszabbítása nem kizárt, csak azt mondja ki, hogy a jogorvoslat benyújtására nyitva álló határidő a távolságra tekintettel nem hosszabbítható meg, e határidőnek a távolságtól eltérő más okból történő meghosszabbítása nem kizárt. ${ }^{19} \mathrm{~A}$ főtanácsnoki érvelés szerint az a tény, hogy a határidőnek csak a távolságra tekintettel történő meghosszabbítása kifejezetten tiltott, annak a jele, hogy az uniós jogalkotó nem akarta kizárni a rendelet 33 . cikkének (5) bekezdésében megállapított határidő egyéb okokból történő meghosszabbítását. Mint látjuk azonban, a Bíróság nem tette teljesen magáévá ezt a gondolatmenetet.

\footnotetext{
18 Ezen értékelés során ez a bíróság többek között figyelembe veheti azt, hogy a végrehajthatóságot megállapító határozat azt megelőzően történő végrehajtása, hogy e határozatot a végrehajtás alá vont személy részére kézbesítették, indokolatlanul sértette e személynek a Charta 47. cikkében biztosított hatékony jogorvoslathoz való jogát.

19 Ezt az álláspontot képviseli a nemzetközi magánjog területén számos kiemelkedő szerző is, lásd pl. : Schlosser P. EU-Zivilprozessrecht. 2. kiadás. München ; Beck, 2003. 276. o. 9. sz. ; Oberhammer P. Art. 43. Kommentar zur Zivilprozessordnung. 10. kötet. 22. kiadás. Tübingen : Mohr Siebeck, 2011. 686. o. 11. sz. ; Mankowski P. Art 33. Brussels IIbis Regulation. München : Sellier, 2012. 312. o. 38. sz. ; Paraschas K. VO (EG) 2201/2003 Art. 33. Internationaler Rechtsverkehr in Zivil- und Handelssachen. 54. kiadás. München : Beck, 2018. 8. sz.
} 


\subsection{A C-375/18. sz. ügyben előterjesztett kérdésröl}

A negyedik kérdésével a kérdést előterjesztő ír bíróság azt szerette volna megtudni, hogy a rendeletet úgy kell-e értelmezni, hogy azzal olyan helyzetben, mint amely az alapeljárás tárgya, ellentétes az, hogy a tagállami bíróság valamely másik tagállam közjogi szervezetével szemben ideiglenes intézkedés formájában védelmi intézkedéseket fogadjon el, megtiltva e szervezetnek, hogy e másik tagállam bíróságai előtt az ott tartózkodó gyerekek örökbefogadására irányuló eljárást indítsanak vagy folytassanak le.

A Bíróság már korábban kimondta, hogy a rendelet lehetővé teszi az e cikkben említett bíróságok számára, hogy ideiglenes vagy védelmi intézkedéseket hozzanak, feltéve hogy e bíróságok a szülöi felelősséggel kapcsolatos joghatóságukat nem az e rendelet II. fejezetének 2. szakaszában foglalt cikkek valamelyikére alapítják. ${ }^{20} \mathrm{E}$ bíróságok csak akkor jogosultak ideiglenes vagy védelmi intézkedéseket hozni, ha a következő három feltétel együttesen fennáll:

- a szóban forgó intézkedéseknek sürgőseknek kell lenniük;

- azokat az e bíróságok székhelye szerinti tagállamban található személyekre vagy vagyontárgyakra vonatkozóan kell meghozni, valamint;

- ideiglenes jellegűeknek kell lenniük. ${ }^{21}$

Ebböl az is következik, hogy az olyan határozat, amelyből nem derül ki, hogy azt az ügy érdemével kapcsolatban joghatósággal rendelkező vagy állítólag joghatósággal rendelkező bíróság hozta, nem feltétlenül tartozik a rendelet 20. cikkének hatálya alá, hanem kizárólag akkor vonatkozik rá e rendelkezés, ha e határozat megfelel az e rendelkezésben elöírt feltételeknek. ${ }^{22}$ A Bíróság szerint meg kell állapítani, hogy az alapeljárás tárgyát képező ideiglenes intézkedés iránti kérelem nem olyan személyekre vonatkozik, akik a kérdést előterjesztő bíróság székhelye szerinti tagállamban tartózkodnak, és így nem teljesíti a fentebb részletezett feltételeket. A Bíróság válasza ezért az volt, hogy nem tartozik a rendelet 20 . cikkének hatálya alá az olyan védelmi intézkedés, mint amilyen az alapügy tárgyát képező ideiglenes intézkedés, amelyet valamely tagállami bíróságtól valamely másik tagállam közjogi szervezetével szemben kérnek, megtiltva e szervezetnek, hogy az e másik tagállam bíróságai előtt az ott tartózkodó gyerekek örökbefogadására irányuló eljárást indítsanak vagy folytassanak le.

A tagállami bíróság végül arra is választ várt, hogy az ilyen ideiglenes intézkedés annak megtiltásához vezetne-e, hogy a HCC a hatáskörrel

20 Lásd ehhez : 2010. július 15-i Purrucker ítélet, C-256/09, EU:C:2010:437, 63. pont.

21 Lásd ehhe z: 2010. július 15-i Purrucker ítélet, C-256/09, EU:C:2010:437, 77. pont, valamint az ott hivatkozott ítélkezési gyakorlat.

22 Lásd ehhez : 2010. július 15-i Purrucker ítélet, C-256/09, EU:C:2010:437, 78. pont. 
rendelkező angol bíróságokhoz forduljon, ami korábbi ítéletekben megtiltott ún. anti-suit injunctionhöz lenne hasonlatos. A Bíróság ezen korábbi ügyekben kimondta, hogy hogy az anti-suit injunction, vagyis az olyan intézkedés, amely célja megtiltani valakinek, hogy másik tagállam bíróságai előtt eljárást indítson vagy folytasson, nem egyeztethető össze a polgári és kereskedelmi ügyekben a joghatóságról és a bírósági határozatok végrehajtásáról szóló, 1968. szeptember 27-én megkötött egyezménnyel és a rendelettel, mivel az ilyen intézkedés nem tartja tiszteletben azon elvet, amely szerint valamennyi bíróság jogosult a rá alkalmazandó szabályok alapján megvizsgálni, hogy rendelkezik-e joghatósággal az elé terjesztett jogvita eldöntésére. A másik tagállam bíróságának hatáskörébe való ilyen beavatkozás egyébiránt összeegyeztethetetlen a kölcsönös bizalom elvével, amely lehetővé tette a joghatóságok kötelező rendszerének bevezetését, amelyet az e jogforrások hatálya alá tartozó összes bíróságnak be kell tartania. ${ }^{23}$ A Bíróság ebben az ügyben megállapította, hogy a rendelet és különösen annak 26. cikke nem teheti lehetővé olyan ideiglenes intézkedés meghozatalát, amelynek célja megtiltani a HCC számára, hogy az Egyesült Királyságban a gyermekek örökbefogadásával kapcsolatos bírósági eljárást indítson vagy vitassa az angol bíróságok vonatkozó joghatóságát. A Bíróság ezzel egyidejüleg azonban azt is kimondta, hogy az olyan ideiglenes intézkedésnek, mint amelyet az érintett szülők kérnek nem célja és nem következménye a HCC abban való megakadályozása, hogy angol bírósághoz forduljon ugyanazon tárggyal kapcsolatban, mint a kérdést előterjesztő bíróság előtt folyamatban lévő jogvita tárgya, mivel az Egyesült Királyságban indított vagy folytatott bírósági örökbefogadási eljárásnak eltérő a célja és a hatása, mint a rendelet szerinti, a gyermekek visszavitelére és az érintett szülök jogorvoslati jogának védelmére irányuló eljárásnak. A rendelet szerint az ezen örökbefogadásról szóló határozat, és az azt előkészítő intézkedések nem tartoznak a rendelet hatálya alá. A Bíróság a negyedik kérdésre így azt a választ adta, hogy a rendeletet úgy kell értelmezni, hogy azzal olyan helyzetben, mint amely az alapeljárás tárgya, nem ellentétes az, hogy a tagállami bíróság valamely másik tagállam közjogi szervezetével szemben ideiglenes intézkedés formájában védelmi intézkedéseket fogadjon el, megtiltva e szervezetnek, hogy e másik tagállam bíróságai előtt az ott tartózkodó gyerekek örökbefogadására irányuló eljárást indítsanak vagy folytassanak le.

23 Lásd ehhez: 2004. április 27-i Turner ítélet, C-159/02, EU:C:2004:228, 24. és 25. pont ; 2009. február 10-i Allianz és Generali Assicurazioni Generali ítélet, C-185/07, EU:C:2009:69, 29. és 30. pont ; 2015. május 13-i Gazprom ítélet, C-536/13, EU:C:2015:316, 33. és 34. pont. 


\section{KÖVETKEZTETÉSEK}

Ítéletében a Bíróság megerősítette a korábbi hasonló tárgyú ügyekben kialakított ítélkezési gyakorlatát. Az alapügyben alkalmazandó 2201/2003/EK rendeletet a Bíróság hatálybalépése óta már több tucat alkalommal értelmezte. A jogszabály 33. cikke tekintetében azonban ez volt az első alkalom, amikor egy tagállami bíróság előzetes döntéshozatali eljárás keretében megkereste a Bíróságot. A 11. cikket illetően pedig egyetlen másik döntés született eddig egy görög bíróság kérelmére indult ügyben. ${ }^{24}$ Abban a döntésében a Bíróság kimondta, hogy az olyan helyzetben, amelyben a szülők közös szándékának megfelelően a gyermek azon tagállamtól eltérő tagállamban született, és tartózkodott több hónapig megszakítás nélkül az édesanyjával, amelyben a szülők a gyermek születése előtt szokásos tartózkodási hellyel rendelkeztek, a szülők azon eredeti szándéka, hogy az anya a gyermekkel együtt visszatér az utóbbi tagállamba, nem teszi lehetővé annak megállapítását, hogy e gyermeknek ott található a rendelet értelmében vett "szokásos tartózkodási helye". Következésképpen ilyen helyzetben az, hogy az anya megtagadta az e tagállamba a gyerekkel való visszatérést, nem tekinthető a gyermek jogellenes elvitelének vagy visszatartásának.

\section{ÖSSZEFOGLALÁS}

Az Európai Unió Bírósága egy 2018 őszén hozott ítéletében értelmezte a házassági ügyekben és a szülöi felelősségre vonatkozó eljárásokban a joghatóságról, valamint a határozatok elismeréséről és végrehajtásáról szóló, 2003. november 27-i 2201/2003/EK tanácsi rendelet két cikkét. Ítéletében a Bíróság megerősítette a korábbi hasonló tárgyú ügyekben kialakított ítélkezési gyakorlatát. A tanulmány bemutatja az ügy jogi hátterét, a tényállásbeli előzményeket, a tagállami bíróság által az előzetes döntéshozatali eljárásban feltett kérdéseket, és a Bíróság arra adott válaszait a jogi indokolásukkal együtt, különös tekintettel a fötanácsnoki indítványtól eltérő részekben.

\section{Information about author:}

Angyal Zoltán, Ph. D.,

Egyetemi docens, Miskolci Egyetem, Állam-és Jogtudományi Kar

\footnotetext{
24 A Bíróság 2017. június 8-i ítélete a C-111/17. sz. ügyben, OL kontra PQ, A Monomeles Protodikeio Athinon (Görögország) által benyújtott előzetes döntéshozatal iránti kérelme.
} 